\title{
Front Matter: Volume 10351
}

, "Front Matter: Volume 10351," Proc. SPIE 10351, UV and Higher Energy Photonics: From Materials to Applications 2017, 1035101 (11 September 2017); doi: 10.1117/12.2296951

SPIE Event: SPIE Nanoscience + Engineering, 2017, San Diego, California, United SPIE. States 


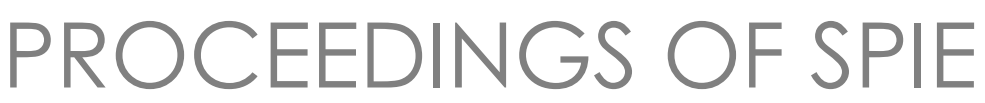

\title{
UV and Higher Energy Photonics: From Materials to Applications 2017
}

\author{
Gilles Lérondel \\ Satoshi Kawata \\ Yong-Hoon Cho \\ Editors
}

6-7 August 2017

San Diego, California, United States

Sponsored and Published by

SPIE 
The papers in this volume were part of the technical conference cited on the cover and title page. Papers were selected and subject to review by the editors and conference program committee. Some conference presentations may not be available for publication. Additional papers and presentation recordings may be available online in the SPIE Digital Library at SPIEDigitalLibrary.org.

The papers reflect the work and thoughts of the authors and are published herein as submitted. The publisher is not responsible for the validity of the information or for any outcomes resulting from reliance thereon.

Please use the following format to cite material from these proceedings:

Author(s), "Title of Paper," in UV and Higher Energy Photonics: From Materials to Applications 2017, edited by Gilles Lérondel, Satoshi Kawata, Yong-Hoon Cho, Proceedings of SPIE Vol. 10351 (SPIE, Bellingham, WA, 2017) Seven-digit Article CID Number.

ISSN: 0277-786X

ISSN: 1996-756X (electronic)

ISBN: 9781510611597

ISBN: 9781510611603 (electronic)

Published by

SPIE

P.O. Box 10, Bellingham, Washington 98227-0010 USA

Telephone +1 3606763290 (Pacific Time) · Fax +1360647 1445

SPIE.org

Copyright @ 2017, Society of Photo-Optical Instrumentation Engineers.

Copying of material in this book for internal or personal use, or for the internal or personal use of specific clients, beyond the fair use provisions granted by the U.S. Copyright Law is authorized by SPIE subject to payment of copying fees. The Transactional Reporting Service base fee for this volume is $\$ 18.00$ per article (or portion thereof), which should be paid directly to the Copyright Clearance Center (CCC), 222 Rosewood Drive, Danvers, MA 01923. Payment may also be made electronically through CCC Online at copyright.com. Other copying for republication, resale, advertising or promotion, or any form of systematic or multiple reproduction of any material in this book is prohibited except with permission in writing from the publisher. The CCC fee code is 0277 $786 \times / 17 / \$ 18.00$.

Printed in the United States of America.

Publication of record for individual papers is online in the SPIE Digital Library.

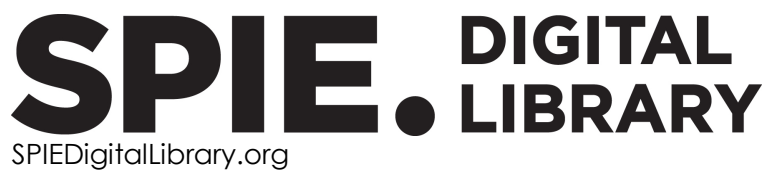

Paper Numbering: Proceedings of SPIE follow an e-First publication model. A unique citation identifier (CID) number is assigned to each article at the time of publication. Utilization of CIDs allows articles to be fully citable as soon as they are published online, and connects the same identifier to all online and print versions of the publication. SPIE uses a seven-digit CID article numbering system structured as follows:

- The first five digits correspond to the SPIE volume number.

- The last two digits indicate publication order within the volume using a Base 36 numbering system employing both numerals and letters. These two-number sets start with 00, 01, 02, 03, 04, 05, 06, 07, 08, 09, OA, OB ... 0Z, followed by 10-1Z, 20-2Z, etc. The CID Number appears on each page of the manuscript. 


\title{
Contents
}

\author{
$\checkmark$ Authors \\ vii Conference Committee
}

UV AND HIGHER ENERGY MATERIALS AND LIGHT SOURCES I

1035105 A design of energy detector for ArF excimer lasers [10351-4]

UV AND HIGHER ENERGY MATERIALS AND LIGHT SOURCES II

1035107 Performance stability of reflection-mode AIGaN photocathode under different preparation methods [10351-6]

UV AND HIGHER ENERGY MATERIALS AND LIGHT SOURCES III

10351 OB Recent advances in metals for plasmonics applications in the UV range (Invited Paper) [10351-10]

10351 OD Aluminum nanostructures for ultraviolet plasmonics (Invited Paper) [10351-12]

APPLICATIONS OF UV, DEEP UV, VACUUM UV, AND EXTREME UV PHOTONICS

10351 OG Changes in electronic states of molecules resulted from interactions in the condensed phase (Invited Paper) [10351-15] 
Proc. of SPIE Vol. 10351 1035101-4

Downloaded From: https://www.spiedigitallibrary.org/conference-proceedings-of-spie on 26 Apr 2023 Terms of Use: https://www.spiedigitallibrary.org/terms-of-use 


\section{Authors}

Numbers in the index correspond to the last two digits of the seven-digit citation identifier (CID) article numbering system used in Proceedings of SPIE. The first five digits reflect the volume number. Base 36 numbering is employed for the last two digits and indicates the order of articles within the volume. Numbers start with 00, 01, 02, 03, 04, 05, 06, 07, 08, 09, 0A, OB...0Z, followed by 10-1Z, 20-2Z, etc.

Alcaraz de la Osa, R., OB

Bai, Lujun, 05

Ehara, Masahiro, OG

Everitt, H. O., OB

Feng, Zebin, 05

Gérard, Davy, OD

González, F., OB

Gutiérrez, Y., OB

Han, Xiaoquan, 05

Hao, Guanghui, 07

Khlopin, Dmitry, OD

Martin, Jérôme, OD

Maurer, Thomas, OD

Moreno, F., OB

Morisawa, Yusuke, OG

Ortiz, D., OB

Ozaki, Yukihiro, OG

Plain, Jérôme, OD

Proust, Julien, OD

Qian, Yunsheng, 07

Qiu, Yafeng, 07

Saiz, J. M., OB

Sanz, J. M., OB

Schuermans, Silvère, $O D$

Tachibana, Shin, OG

Ueno, Nami, OG

Zhang, Feifei, OD

Zhang, Junju, 07

Zhang, Yijun, 07

Zhou, Yi, 05 
Proc. of SPIE Vol. 10351 1035101-6

Downloaded From: https://www.spiedigitallibrary.org/conference-proceedings-of-spie on 26 Apr 2023 Terms of Use: https://www.spiedigitallibrary.org/terms-of-use 


\section{Conference Committee}

Symposium Chairs

Harry A. Atwater Jr., California Institute of Technology (United States)

Nikolay I. Zheludev, Optoelectronics Research Centre

(United Kingdom) and Nanyang Technological University

(Singapore)

Symposium Co-chairs

James G. Grote, Air Force Research Laboratory (United States)

David L. Andrews, University of East Anglia (United Kingdom)

Conference Chairs

Gilles Lérondel, Université de Technologie de Troyes (France)

Satoshi Kawata, Osaka University (Japan)

Yong-Hoon Cho, KAIST (Korea, Republic of)

Conference Program Committee

Sanford A. Asher, University of Pittsburgh (United States)

Steve Blair, The University of Utah (United States)

Zhanghai Chen, Fudan University (China)

Yasin Ekinci, Paul Scherrer Institut (Switzerland)

Naomi J. Halas, Rice University (United States)

Hans D. Hallen, North Carolina State University (United States)

Chennupati Jagadish, The Australian National University (Australia)

Junyong Kang, Xiamen University (China)

Yoichi Kawakami, Kyoto University (Japan)

Jong Kyu Kim, Pohang University of Science and Technology (Korea, Republic of)

Paul T. Matsudaira, National University of Singapore (Singapore)

Eva Monroy, CEA Grenoble (France)

Keith A. Nugent, University of Melbourne (Australia)

Yukihiro Ozaki, Kwansei Gakuin University (Japan)

Jérôme Plain, Université de Technologie de Troyes (France)

Atsushi Taguchi, Osaka University (Japan)

Richard P. Van Duyne, Northwestern University (United States)

Remo Proietti Zaccaria, Istituto Italiano di Tecnologia (Italy) 
Session Chairs

1 UV and Higher Energy Materials and Light Sources I

Yong-Hoon Cho, KAIST (Korea, Republic of)

2 UV and Higher Energy Materials and Light Sources II

Xiaohang Li, King Abdullah University of Science and Technology (Saudi Arabia)

3 UV and Higher Energy Materials and Light Sources III

Satoshi Kawata, Osaka University (Japan)

$4 \quad$ UV and Higher Energy Spectroscopy

Fernando Moreno, Universidad de Cantabria (Spain)

5 Applications of UV, Deep UV, Vacuum UV, and Extreme UV Photonics Fernando Moreno, Universidad de Cantabria (Spain)

$6 \quad$ UV and Deep UV Biosensing and Analysis with UV and Higher Energy Photonics

Gilles Lérondel, Université de Technologie de Troyes (France) 